\title{
ORGANISASI SOSIAL DALA'IL KHAIRAT (Studi Pengamal Dala'il Khairat K.H Ahmad Basyir Kudus)
}

\author{
Abdul Jalil \\ Alumnus S-2 Antropologi UGM Yogyakarta \\ Email: sukron_jgj@yaboo.co.id
}

\begin{abstract}
This research will try to find the influence of the spirit of Dala'il Khairat to ward work ethos in improving financial of the santri (student). More over this research is trying to observe the processes being done by the student in developing business in obtaining the success. Qualitative method is applied through deep interview, participation observation and documentation in order to obtain the data in Pesantren Darul Falah Jekulo Kudus, directed by KH Abmad Basyir as Mujiz of dala'il khairat for those students applying this practices. Economic analysis for those student performing dala'il khairat shows the influence of spirit or the believes of pertaining dala'il toward business improvement. The spirit of dala'il has brought them to be more spirit and having higher work ethos. Additionally, this research shows a concept of the relationship of applying dala'il khairat which is assumed as believes that will improve their financial.
\end{abstract}

Keywords: Spirit; Dala'il Khairat, economic activities, and pertaining

\section{Abstrak}

Penelitian ini bertujuan untuk mengetabui pengarub spirit Dala'il Khairat terhadap etos kerja dan peningkatan ekonomi santri. Selain itu, kajian ini juga berupaya melibat proses-proses yang telab dijalani para pengamal dalam mengembangkan usaba demi meraih kesuksesan di bidang ekonomi. Metode penelitian yang digunakan dalam kajian ini adalah penelitian kualitatif. Penelitian dilakukan di Pesantren Darul Falab Jekulo Kudus pimpinan K.H Abmad Basyir sekaligus sebagai mujiz amalan dala'il khairat bagi para santri yang masib eksis mengamalkan amalan dala'il. Metode pengumpulan data dilakukan melalui observasi partisipasi, wawancara mendalam, dan dokumentasi.

Kajian mengenai aktivitas ekonomi para pengamal dala'il khairat menunjukkan babwa adanya pengarub spirit atau keyakinan terhadap 
pengamalan dalail terhadap peningkatan usaha yang dijalaninya. Spirit dalail telah membawa para pengamal menjadi lebih semangat dan memiliki etos kerja yang tinggi. Kajian ini juga memperlihatkan pemahaman babwa ada bubungan antara amalan dalail khairat yang barangkali bisa diasumsikan sebagai agama bagi pengamal dalail dengan semangat meningkatkan usaha yang dijalani. Dala'il khairat mendorong terjadinya dinamisasi kehidupan ekonomi para pengamalnya.

Kata Kunci: Spirit; Dala'il Khairat, aktivitas ekonomi, dan pengamal.

\section{Latar Belakang Masalah}

Dala'il Khairat merupakan antologi rumusan-rumusan shalawat nabi yang diamalkan sebagai praktek beragama keseharian. Buku ini disusun oleh Syaikh Sulaiman al-Jazuli dari Maroko, kehadirannya di Indonesia dapat ditemukan pada pesantren Darul Falah Kudus Jawa Tengah. Salah satu tata cara ibadah keagamaan yang telah menjadi tradisi masyarakat Arab adalah pembacaan Dala'il Khairat. Fenomena ini dapat dilihat dari pernyataan Husein yang ketika masa mudanya pernah mengecam ayahnya membaca Dala'il Khairat, sebab pembacaan tersebut dianggapnya menyebabkan waktu terbuang secara bodoh (Husein, tt: 123). Hal senada juga dijelaskan oleh Feillard tentang adanya tradisi kaum salaf yang berkembang di negeri-negeri Arab, baik di Mekkah maupun Madinah senantiasa dilakukan masyarakat Islam tradisonalis Indonesia yaitu berupa membaca Dalail Khairat (Feillard, 1999: 11).

Substansi amalan Dala'il Khairat adalah memberikan bimbingan seorang pengamal mencapai sebuah kualitas yang lebih baik dalam rangka mendekatkan diri kepada Tuhan, hal ini dapat disebut sebagai bentuk aktifitas tasawuf atau sebuah pengalaman keberagamaan bagi para pengamalnya. Pengalaman keberagamaan melalui Dala'il Khairat bahkan lebih representatif bila dikaitkan dengan pendapat al-Taftazani yang menyimpulkan bahwa segala bentuk tasawuf yang memiliki aktivitas dengan bercirikan psikis, moral, dan epistemologis merupakan bagian dari pengalaman tasawuf. Seperti perasaan tentram, keihklasan jiwa atau penuh perdamaian, perasaan fana' penuh dengan realitas mutlak, perasaan pencapaian yang mengatasi dimensi ruang dan waktu (al-Taftazani, 1984: 4-6). 
Tradisi dala'il khairat sampai saat ini masih bisa dilihat eksistensinya. Di Indonesia, tradisi Dala'il Khairat dapat dijumpai di pesantren-pesantren salaf di Pulau Jawa, terutama di wilayah Jawa Tengah. Pesantren Darul Falah di desa Jekulo, Kudus serta pengamal luar pesantren yang berafiliasi dengan K.H Ahmad Basyir adalah beberapa komunitas santri yang menjadikan tradisi Dala' $i l$ Khairat sebagai tradisi yang bersifat sunnah muakkadah. Perkembangan tradisi Dala'il Khairat di Indonesia ini tentunya menjadi suatu fenomena yang menarik untuk diteliti, mengingat tradisi ini berkaitan erat dengan etos kewirausahaan yang dipercaya dapat memberikan berkah keberhasilan usaha.

Salah satu tokoh Spritual Islam di Indonesia yang masih aktif memberikan bimbingan dan konseling agama dengan metode do'a atau amalan dala'il khairat pada umat adalah K.H.Ahmad Basir. Kyai karismatik ini berasal dari Jekulo Kudus Jawa Tengah dan merupakan pengasuh Pondok Pesantren Darul Falah (PPDF). Biasanya materi pokok bimbingan dan konseling yang diminta umat adalah bagaimana cara mencapai kehidupan dunia dan akherat dengan sukses dan diridhohi Allah. Tokoh Spritual dari daerah pantura ini, memberikan bimbingan dan konseling agama pada santri yang masih mukim atau santri yang tidak mukim dengan menggunakan metode memperbanyak membaca shalawat Nabi Muhammad SAW yang terkumpul dalam kitab Dala'il Khairat atau dengan membaca kitab al-Quran 30 Juz sampai selesai. Untuk mendukung kesuksesan amalan tersebut, biasanya santri juga dianjurkan untuk menjalankan laku Puasa Dala'il yaitu puasa tahunan yang pernah dipraktekkan oleh para Nabi sebelum syari'at Nabi Muhammad SAW.

Kajian ini difokuskan mengenai para pengamal Dala'il Khairat terutama bagi mereka yang sudah keluar dari pesantren atau hanya nagalap barokah untuk amalan dala'il. Mereka umumnya sudah berumah tangga dan mengembangkan bisnis usaha, baik di Jawa Tengah, Jawa Barat, dan Daerah Istimewa Yogyakarta, meskipun dalam kenyataannya, penelitian ini juga melibatkan informan dari para pengurus, para santri, maupun mujizatau guru pengamal dala'il. Pengambilan tiga wilayah tersebut, sebagai sampel bagaimana para pengamal di daerah tertentu dalam mengembang- 
kan bisnisnya dan mengamalkan dalail khairat. Metode pengumpulan data dilakukan melalui observasi partisipasi, wawancara mendalam, dan dokumentasi. Sumber data dikumpulkan dari informan yang meliputi mujiz dala'il khairat, para pengurus pesantren, para santri, tokoh masyarakat, dan para alumni pengamal dala'il khairat lainnya.

\section{Permasalahan}

Dari fenomena yang saya uraikan di atas timbul pertanyaan yang menarik, bagaimanakah spirit dala'il Khairat memberi pengaruh terhadap etos kerja dan peningkatan ekonomi santri?. Bagaimanakah bentuk ikhtiar atau usaha para santri pengamal Dala'il Khairat dalam meraih kesuksesan di bidang ekonomi?

\section{Metode Penelitian}

Dua pertanyaan tersebut akan saya jawab dengan menggunakan beberapa faktor yang mempengaruhi. Pertama, dengan melihat aktivitas ekonomi para pengamal dapat ditunjukkan adanya pengaruh spirit atau keyakinan terhadap peningkatan usaha yang dijalani, dalam bahasa lain, adanya pengalaman spiritual ketika menjalani amalan; Kedua, keterlibatan para pengamal dalam berbagai kegiatan keberagamaan, sehingga terbangun relasi sosial dengan masyarakat sekitar cukup kuat, apalagi ketika dalam kegiatan khaul muallif syaikh Sulaiman al-Jazuli; Ketiga, kuatnya pengembangan potensi dalam diri masing-masing pengamal; Keempat, adanya keseimbangan waktu dalam pengembangan usaha dengan amalan; Kelima legitimasi peran pemerintah setempat; Keenam, dalam mengelola usaha bersama dengan partnernya, mereka mendasarkan pada sifatsifat kejujuran, keterbukaan, dan kebersamaan.

Untuk menjawab pertanyaan tersebut, saya telah melakukan penelitian lapangan. Penelitian ini dilakukan di pondok pesantren Darul Falah Kudus sebagai basis tempat para pengamal meminta amalan dala'il kepada mujiz K.H Ahmad Basyir. Mengapa amalan Dala'ilnya K.H Ahmad Basyir dan bukan tokoh yang lain, karena amalan ini selain para pengamal mendapatkan amalan berupa wirid sholawat yang tersusun dalam kitab Naylul Masarrat fi Taskhikhi 
Dala'ilil Khairaiti yang sudah umum diistilahkan dengan kitab Dala'il karya syaikh Sulaiman al-Jazuli, juga ada tuntunan puasa minimal tiga tahun berturut-turut. Sementara amalan Dala'il yang lain hanya sekedar membaca apa yang ada dalam kitab Dala'il tersebut. Termasuk tiga informan dalam penelitian ini, masing-masing dalam satu transmisi K.H Ahmad Basyir.

Metode yang saya gunakan adalah data primer dan data sekunder. Data primer, diperoleh melalui observasi, wawancara, dan dokumentasi, sedangkan data sekunder diperoleh melalui studi pustaka yaitu dengan memanfaatkan buku berbahasa Arab karya Syaikh Sulaiman al-Jazuli yang telah ditasbih kembali oleh K.H. Ahmad Basyir selaku Mujiz. Buku ini dipilih karena merupakan buku wajib yang selalu dimiliki setiap calon pengamal yang hendak memulai amalan dala'il khairat.

Dalam penelitian ini, peneliti mengumpulkan data-data yang berkaitan dengan aktivitas para pengamal Dala'il Khairat santri K.H. Ahmad Basyir Kudus. Data dalam kajian ini, saya peroleh melalui metode observasi partisipasi dan wawancara mendalam. Aspek-aspek yang saya observasi adalah santri di lingkungan pesantren Darul Falah yang meliputi: santri dan pengurus pondok, kegiatan amalan wirid, aktifitas sehari-hari para pengamal, serta proses pemberian ijazah bagi para calon pengamal. Sementara itu observasi untuk informan di luar pesantren, saya lakukan dengan mengamati usahanya secara langsung, termasuk jumlah karyawan dan sistem manajemen yang diterapkan oleh masing-masing pemilik perusahaan itu. Pengamatan penting disini karena memungkinkan peneliti untuk melihat dunia sebagaimana yang dilihat oleh subjek penelitian. Pengamatan juga memungkinkan peneliti merasakan apa yang dirasakan dan dihayati oleh subyek penelitian. Pengamatan memberikan keleluasan kepada peneliti untuk memperoleh informasi dari data-data yang berkaitan dengan aktivitas para pengamal Dala'il Khairat santri K.H. Ahmad Basyir Kudus yang berkaitan dengan pengaruh spirit Dala'il Khairat terhadap perilaku santri dalam mencapai kesuksesan ekonomi.

Penelitian ini menggunakan tehnik wawancara tidak terstruktur, artinya penulis mengajukan pertanyaan secara bebas tetapi 
dengan tetap menggunakan pedoman wawancara yang memuat pokok-pokok kerangka pertanyaan yang akan diteliti. Wawancara tidak terstruktur dilakukan dengan tujuan untuk memperoleh keterangan secara umum tentang aktivitas para pengamal Dala'il Khairat santri K.H. Ahmad Basyir Kudus yang berkaitan dengan spirit Dala'il Khairat terhadap peningkatan ekonomi santri.

\section{Pembahasan}

Studi tentang agama dan ekonomi bertujuan untuk menyatakan kemungkinan adanya hubungan antara pola perilaku ekonomi masyarakat dengan kesalehan agama. Hal ini ditandai dengan banyaknya pemeluk agama yang memiliki kesalehan agama yang kuat, berpengaruh dalam usaha yang dijalaninya. Menurut Weber, kehadiran semangat kapitalisme yang merupakan aspek sentral modern telah menggantikan tradisionalisme dalam kehidupan ekonomi. Konsep semangat yang ditawarkan Weber dalam kaitannya dengan semangat kapitalisme mengacu pada suatu jenis tindakan sosial yang melibatkan pengejaran keuntungan maksimum dengan perhitungan rasional (Weber, 2006: 108). Weber menjelaskan bahwa manusia memiliki minat-minat ideal dan material sehingga aspek tertentu dalam etika Protestan merupakan perangsang kuat dalam menumbuhkan sistem ekonomi kapitalis. Etika protestan memberi tekanan pada usaha-usaha menghindari kemalasan, menekankan kerajinan, teratur dalam bekerja, disiplin dan bersemangat tinggi untuk melaksanakan tugas dalam semua sendi kehidupan, khususnya dalam aspek pekerjaan dan kegiatan ekonomi (2006: 105-115). Baginya, Islam dengan ajaran-ajarannya seperti sembahyang, puasa, ibadah haji, menghindari segala bentuk makanan dan minuman yang dinyatakan haram, membawa akibatakibat ekonomis. Selain itu larangan judi membawa akibat yang sangat penting terhadap sikap golongan beragama berkenaan dengan usaha-usaha dengan yang spekulatif (Weber, 2006: 33). Weber juga menunjukkan bahwa ketaqwaan dan kesalehan menganut ajaran Islam dalam kondisi tertentu dapat mendinamiskan, memacu, dan mengagresifkan pemeluk Islam dalam melakukan kegiatan-kegiatan bersifat keduniawian secara konsisten dan sistematis (Muhaimin, 1987: 50) 
Terkait dengan adanya kemungkinan pengaruh agama terhadap etos kerja, menurut Sairin (2002: 328), peningkatan ekonomi masyarakat dapat dilakukan dengan mengambil nilai kerja keras dari agama. Setiap agama yang dianut oleh masyarakat tentu mengajarkan kepada penganutnya untuk bekerja keras dalam hidup, karena kerja keras di dunia dianggap sebagai bentuk ibadah, yang kemudian dengan sendirinya akan mendorong pelaksanaan ibadah. Lebih jauh dijelaskan bahwa etos tidak dapat dipisahkan dan bahkan merupakan bagian yang tidak terpisahkan dari sistem kebudayaan. Kebudayaan yang dipahami sebagai sistem gagasan yang dimiliki masyarakat dari proses belajar adalah induk dari etos. Oleh karena itu, setiap masyarakat dan kebudayaan mempunyai etos yang berbeda-beda, termasuk dalam hubungannya dengan etos kerja (Sairin, 2002: 319-320). Baginya ada tiga kriteria orientasi soaial budaya masyarakat, pertama, kerja sebagai kegiatan mencari nafkah semata agar dapat survive. Kedua, kerja sebagai alat untuk mencapai status sosial tertentu, dan ketiga, merupakan upaya mencapai hasil yang lebih baik (Sairin, 2002: 322).

Agama dapat difungsikan sebagai motivator di dalam proses transformasi konseptual, yang secara langsung berkaitan dengan apa yang dimaksudkan Weber sebagai rasionalisasi, yakni organisasi kehidupan sosial ekonomi atas dasar prinsip-prinsip efisiensi (Abdullah, 2003: 262). Agama telah membantu proses sejarah peradaban dengan cara mendorong perubahan dalam orientasi nilai yakni dari masyarakat yang masih terkait pada nilai-nilai magis ke masyarakat yang mempunyai orientasi nilai-nilai rasional. Agama menjadi suatu kekuatan yang menghapuskan ikatan-ikatan tradisional, yang menekankan kehidupan sebagai bagian dari tatanan yang harmoni (Abdullah, 1994: 173).

Dala'il Khairat dapat diartikan sebagai suatu tuntunan serta bimbingan yang dapat mengantarkan seseorang mencapi derajat kebaikan dan keutamaan dengan cara membaca shalawat Nabi dan beberapa do'a wirid lainnya (al-Mahdi, 1980: 16). Kyai Muslih bin Abdurrahman menambahkan bahwa, inti dari amalan Dala'il Khairat terletak pada pembacaan shalawat Nabi yang masybur dan mujarab. Hal ini dimaksudkan sebagai wasilah menuju tercapainya beberapa hajat yaitu: menghilangkan kesusahan, menjernihkan 
hati dan pikiran, menghindarkan bahaya dan bencana, serta mendatangkan kebaikan di dunia dan akherat (Muslih, tt: 2-3).

Dala'il khairat dapat dikatakan sebagai Organisasi Sosial karena mengandung beberapa unsur yang bentuk pilihan seseorang dalam memahami dan mendalami agamanya. Apabila dilihat dari sejarah yang ada, agama Islam seringkali dianggap sebagai agama yang menjadikan masyarakat pemeluknya memiliki etos kerja dan spirit persaingan yang lemah (www.studiislam.com). Hal ini justru kontradiktif dengan realitas yang dijumpai pada para pengamal Dala'il Khairat yang justru menjadikan Dala'il Khairat sebagai pemantik dalam membangun etos kerja yang kuat. Dalam hal ini dapat dikatakan bahwa dimensi spiritualitas memberikan efek positif dengan memunculkan motivasi tersendiri bagi pengamalnya.

Selain itu, Dala'il Khairat memberikan motivasi tersendiri bagi para pengamalnya, termasuk diantaranya dalam upaya membangun dan memajukan kegiatan perekonomian mereka. Dala'il ini juga mendorong para pengamal untuk ikut serta dalam usaha memajukan kegiatan sosial, pendidikan, dan keagamaan masyarakat (Taher dalam Asyari, 1997: 5). Kesan serupa ini sebenarnya juga sudah disinggung Weber pada lingkungan masyarakat Protestan sekte Calvinis. Menurut Weber, agama yang bersemangat modern akan memberikan dorongan atau spirit terhadap pertumbuhan ekonomi kapitalisme. Artinya disini terdapat korelasi antara agama dengan perilaku ekonomi, yakni keduanya saling mempengaruhi dan dipengaruhi oleh perubahan-perubahan yang terjadi pada pranata-pranata yang membentuk masyarakat (Abdullah, 1988:4). Kerja keras merupakan suatu keharusan bagi setiap manusia untuk mencapai kesejahteraan sosial. Weber menyebutkan bahwa sumber motivasi atau semangat seseorang dalam melakukan kerja keras adalah budaya religi masyarakat tersebut (Twikromo dalam Basis, 1993: 392).

Dalam penelitian ini, saya melihat etos kerja para pengamal dalail khairat berdampak pada aktivitas usaha yang ditekuninya, meskipun hal ini secara tidak langsung juga dipengaruhi oleh kondisi atau keadaan, lingkungan dan sebagainya. Artinya bukan murni kesadaran yang menentukan mereka menjadi seorang pelaku usaha. Di luar itu, faktor tersedianya modal dan semangat untuk 
berwirausaha atau menjadi pelaku bisnis adalah sesuatu yang memungkinkan.

Dalam proses pengembangan ekonomi, etos kerja yang terbangun dari amalan Dala'il Khairat-lah yang menjiwai dan menjadi tuntunan para pengamal. Secara sederhana etos kerja diartikan sebagai sikap yang dikehendaki seseorang terhadap kegiatan pekerjaanya. Menurut Abdullah (1979: 3), etos adalah aspek evaluatif yang bersifat menilai. Dala'il khairat yang diamalkan para pengamal dengan disiplin dan penuh tanggung jawab, akan sangat berpengaruh pada kedisiplinan dalam melakukan setiap aktivitas. Mereka selalu mengamalkan dala'il dengan niat ikhlas, bisa menjaga dan membedakan ketika menjadi pengamal dengan yang bukan pengamal. Dala'il khairat menjadi semacam semangat untuk melakukan hal-hal positif seperti: memperteguh kemanusiaan serta memacu kreatifitas dan produktivitas pengamal. Para pengamal meletakkan hasil dari usaha, kekuasaan, dan ilmu pengetahuan bukan sebagai tujuan, tetapi alat perjuangan spiritual yang mencerahkan, membebaskan dan memperteguh kemanusiaan. Pengamalan dala'il tidak semata-mata mengandalkan kemampuan konseptual dalam merencanakan sebuah aktifitas, tetapi komitmen moral dan budi pekerti yang tinggi yang melekat pada para pengamal. Hal inilah yang pada akhirnya mampu mengantarkan mereka untuk melakukan usahanya secara sehat.

Pesantren Darul Falah Kudus merupakan tempat para pengamal mengawali amalan dala'il, meskipun secara keseluruhan santri di pesantren ini tidak selalu mengamalkan dala'il, namun secara umum, dapat dikatakan 90\% dari keseluruhan santri mengamalkan dala'il, baik untuk santri putri dan biasa amalan dala'il qur'an, sementara santri putra secara umum mengmalkan dala'il qur'an selama satu tahun dan dilanjutkan dengan amalan dala'il khairat selama tiga tahun. Dalam penelitian ini, saya hanya mengambil tiga informan dengan latar belakang daerah dan aneka ragam usaha yang berbeda-beda sebagai sampel bahwa para pengamal ini dengan kekuatan spirit dala'i khairat yang telah dimiliki, mampu mengantarkan mereka memiliki semangat kerja keras dan akhirnya menumbuhkan kesuksesan di bidang ekonomi. Praktek pengamal Dala'il Khairat di mulai ketika mereka meng- 
implementasikan amalan dalam kehidupan kesehariannya, termasuk didalamnya pasang surut mereka dalam menjalani usaha bisnisnya.

Umumnya para pengamal Dala'il Khairat adalah para kaum laki-laki, sementara kebanyakan santri putri tidak mengamalkan Dala'il Khairat rata-rata disebabkan beratnya kewajiban untuk menjalankan puasa selama tiga tahun. Pada umumnya mereka hanya menjalankan amalan dengan membaca wirid yang ada dalam kitab Dala'il Khairat. Hal ini diperbolehkan, mengingat kadar rintangan dan halangan yang dihadapi kaum wanita jauh lebih berat dibanding laki-laki. Setiap datang bulan atau haid, seorang wanita yang menjalankan puasa Dala'il Khairat harus berhenti. Puasa yang ditinggalkan ini tidak bisa dihitung, dan harus diganti setelah mereka selesai menjalankan puasa selama tiga tahun.

Dalam tulisan ini akan dibahas dua hal penting pertama, pengaruh spirit Dala'il Khairat terhadap etos kerja dan peningkatan ekonomi santri. Dalam hal ini ada empat penyebab keberhasilan ekonomi santri, diantaranya: adanya pengalaman spiritual dalam menjalani amalan, dan tiga hal lain sebagai sifat maupun prinsip dalam menjalankan usaha bisnisnya yakni dimilikinya sifat kejujuran, keterbukaan, dan kebersamaan. Kedua, bentuk-bentuk usaha atau ikhtiar santri pengamal Dala'il Khairat dalam meraih kesuksesan dibidang ekonomi melalui pengembangan potensi diri, keseimbangan waktu dalam pengembangan usaha, dan relasi dengan pemerintah yang telah dibangun.

Pengalaman spiritual dimaksudkan bahwa dengan keyakinan melaksanakan wirid Dala'il Khairat, para pengamal mendapatkan spirit untuk mencapai sebuah kesuksesan. Hal ini banyak berkaitan dengan visi misi ke- Dala'il Khairat-an. Seperti pesan K.H Ahmad Basyir bahwa amalan Dala'il Khairat berupa bacaan shalawat, maka barang siapa yang sering membiasakan bacaan shalawat nabi, maka akan tercapai cita-citanya, dipermudah tujuan hidupnya, dapat terhindar dari kesusahan dan akan diperbanyak rizkinya, meskipun faktor lain berupa semangat bekerja yang dibangun oleh masingmasing pengamal juga menentukan sebagai sebuah keberhasilan. Tentu pengamalannya dalam konsep aturan yang semestinya, misalnya calon pengamal harus melalui sowan atau menghadap K.H Ahmad Basyir untuk meminta ijazah atau amalan Dala'il 
Khairat, setelah mendapatkan ijin untuk mengamalkan, calon pengamal akan melalui tahapan-tahapan amalan berupa diijinkannya mengamalkan Dala'il Khairat atau adanya proses ijazah yakni sumpah seseorang untuk mengamalkan dan memegang teguh tata cara yang berlaku bagi pengamal dala'il. Dan yang terpenting dalam proses pemberian ijazah adalah seorang guru memberikan nasehat tentang kedudukan shalawat, makna, dan keutamaannya. Tahap selanjutnya amalan wirid, atau dzikir yang dilakukan secara kontinyu pada waktu tertentu dan dimanapun berada. Wirid disini diartikan sebagai petunjuk yang diturunkan ke dalam hati seseorang tanpa diminta. Istilah ini sering dihubungkan dengan pengetahuan intuitif atau kesanggupan dalam mencapai pengetahuan dengan pemahaman secara langsung tanpa melalui proses berfikir, ilham atau petunjuk yang diberikan Tuhan dan sejenisnya. Tahap berikutnya amalan puasa Dala'il Khairat atau puasa selama kurang lebih tiga tahun dan dilakukan secara terus menerus dengan dibarengi pembacaan wirid shalawat yang terkumpul dalam kitab Dala'il Khairat..

Faktor lain yang mempengaruhi peningkatan ekonomi adalah terbangunnya sifat jujur, saling terbuka, dan menjunjung tinggi nilai kebersamaan. Misalnya kejujuran, baik terhadap diri sendiri, teman kerja, relasi bisnis, dan karyawana. Meraka para pengamal selalu memberikan kepercayaan penuh kepada setiap karyawan dalam menjalankan pekerjaannya masing-masing. Kejujuran juga diartikan sebagai kejujuran untuk tidak mengambil keuntungan sendiri, kejujuran atas harga yang layak dan wajar, kejujuran atas mutu barang yang dijual, kejujuran atas tuntutan hidup bersama.

Para pengamal juga tidak lepas dari berbagai ujian maupun cobaan ketika menjalani amalan Dala'il Khairat, namun itu semua dimaknai sebagai sebuah tantangan dan dinamika dalam menjalani hidup. Pengakuan Asrom misalnya bahwa dalam setiap usaha yang dijalaninya, sering kali menemui beragam rintangan dan hambatan. Setiap dua tahun menjalani usahanya dengan lancar, seringkali dua tahun berikutnya berjalan tersendat. Hal serupa ini sempat terjadi pada tahun 2006 dan 2007.

Perusahaan yang dikembangkannya selalu dinamis. Artinya dari mulai menyediakan bahan mebel sampai kebutuhan bahan mentah dari Jepara untuk kemudian diperbaiki sendiri dengan biaya 
dan tenaga yang jauh lebih murah dari pada membeli dalam bentuk jadi. Dengan terobosan yang serupa, pada tahun 1989, didirikan pabrik atau industri rotan sebagai bahan baku bagi pembeli yang menginginkan industri kayu sebagai bahan mentah.

Sebut saja usaha furniture. Awalnya usaha ini sangat prospektif dan berkembang dengan stabil di Yogyakarta, bahkan dapat dikatakan sebagai awal kebangkitan perekonomian Asrom. Justru karena berharap ingin mendapatkan penghasilan yang lebih, cabang baru yang dibuka di Jakarta pada tahun 1996, ternyata kurang menguntungkan. Setelah dipelajari dan dievaluasi, keputusan untuk membuka cabang baru ini kurang tepat. Yang lebih baik justru dengan memperbanyak jaringan. Selain dapat mempergunakan orang pribumi sebagai tenaga kerjanya, usaha semacam ini juga tidak dikategorikan sebagai perdagangan monopoli. Pada saat terjadi gempa tanggal 26 Mei tahun 2006, sebagian besar perusahaan Asrom juga terkena dampaknya, terutama yang berada di Jalan Parang Tritis. Usahanya yang semula berupa warung makan "wong kampung", sekarang berganti menjadi tempat jual-beli material.

Lain halnya Suharnoto, dia sosok yang dekat dengan dunia seni. Hal ini disebabkan dunia usahanya yang lebih terkait dengan entertainmen, termasuk diantaranya: event organizer, property, dan production house. Semua usahanya berada dalam wadah Cakrawala Production yang berdiri pada tahun 1989 dan bergerak di bidang rental sound system. Pada tahun 1994 sampai tahun 2001, Cakrawala Production telah dipercaya untuk mengisi berbagai acara di arena hiburan di Semarang Jawa Tengah atau biasa disebut dengan PRPP. Tepat pada tahun 1996, nama Cakrawala Production berubah menjadi production house dan pada tahun inilah mulai Go Internasional.

Usaha yang dijalani Suharnoto, pada kenyataannya tidak selalu berjalan mulus dan stabil. Artinya dengan sumber daya manusia yang berjumlah 30 orang karyawan, Suharnoto tidak selalu melibatkan kesemuanya dalam setiap event. Hal ini dilakukan karena penyelenggaraan event tertentu belum cukup membiayai harga produksi. Oleh karena itu CV.Cakrawala production sekarang ini sedang melakukan penataan manajemen yang diantaranya dilakukan dengan mencoba menawarkan terobosan-terobosan pada 
masing-masing daerah yang memiliki potensi untuk dipublikasikan melalui media. Usaha ini dimulai dari pembuatan stand dan perangkat-perangkatnya untuk kemudian disosialisasikan ke daerahdaerah melalui pameran atau expo potensi daerah. Selain itu kerjasama antar sponshorsip juga selalu digalakkan, misalnya dalam promosi potensi daerah bagi pemerintah tertentu. Hal ini dirasa dapat memberikan keuntungan ganda yaitu peningkatan kualitas dan kreatifitas bagi Cakrawala production sendiri serta citra positif bagi target market dari pelanggan.

Sementara usaha yang dijalani Uci ada empat bentuk yaitu: (1) pendidikan, baik yang di pesantren Miftahul Huda atau khusus agama maupun pengelolaan pendidikan yang bekerjasama dengan umum; (2) penggilingan gabah; dan (3) travel Jakarta-Kunigan; dan (4) pembuatan roti yang dikelola dirumahnya sendiri.

Dalam melakukan terobosan baru dalam usaha, Uci biasanya aktif mendatangi setiap even atau expo tertentu yang dapat memberikan semangat baru dan inovasi dalam berusaha, meskipun terkadang sangat jauh dari latar belakang keilmuan yang dimilikinya bahkan tidak ada sama sekali keterkaitan dengan apa yang selama ini dijalaninya. Uci berupaya mengimplementasi semua ide yang diperolehnya dalam setiap even tersebut. Jika sama sekali tidak mampu, Uci tidak segan-segan meminta orang lain untuk menyelesaikannya, meskipun usianya jauh lebih muda. Baginya pekerjaan tersebut dapat dikerjakan teman atau siapapun yang memiliki keahlian. Hal ini semata-mata dilakukan agar usahanya dapat berjalan, sehingga operasional kebutuhan pesantren dan pendidikan, termasuk memberikan kesejahteraan para santri dan insentif para guru pendidiknya, dapat dipenuhi pada waktunya.

Usaha Uci yang masih berjalan tanpa pengawasan yang ketat adalah penggilingan padi dan travel. Sementara itu hasil dari usaha pembuatan roti, lebih banyak digunakan untuk perekonomian keluarga, karena memang menjadi investasi milik sendiri bukan dari pewakaf. Persoalan sering muncul dalam usaha penggilingannya. Hal ini dikarenakan Uci belum mampu melakukan aktivitas selain pada musim panen di daerah sekitarnya. Sumber pemasukan dari alat ini hanya insidental. Jika di sekitar daerah sedang memasuki masa panen, maka penggunaan mesin ini sangat ramai dan akan 
beroperasi sampai hasil panen selesai. Padahal panen raya tidak selalu datang bersamaan. Uci berharap bisa mengambil hasil panen di daerah-daerah, sehingga bisa memperoleh tambahan pendapatan yang lebih besar. Usaha travel Uci bisa dikatakan stabil, karena sistem sudah berjalan dan hanya menerima laporan berkala setiap minggu sekali dalam rapat bersama.

Rintangan atau hambatan yang ada, dimaknai Uci sebagai sebuah peluang dan bukan semata-mata tantangan. Misalnya dalam kasus pembuatan roti yang disebutnya "Roti Primadona. Problem pembuatan roti yang kerapkali dihadapinya adalah ketika ada pesanan roti basah secara mendadak. Artinya roti yang diproduksi Uci ada dua jenis, basah dan kering. Jika kering tidak menjadi masalah jika seharian tidak laku, sementara roti basah terkadang kurang dari permintaaan, dan banyak pula yang kelebihan, sehingga hal ini membuat biaya produksi menjadi lebih mahal.

\section{Kesimpulan}

Dala'il Khairat merupakan salah satu bentuk aktifitas keberagamaan dalam tradisi masyarakat Islam. Sebagai suatu bentuk bimbingan yang berintikan shalawat nabi Muhammad SAW. Dala'il Khairat diyakini mampu mengantarkan para pengamalnya menuju derajat utama, mengingat bahwa dengan pemahaman dan penghayatan terhadap sebuah praktek ibadah sangat berpengaruh bagi pencapaian kualitas pribadi.

Pengamalan Dala'il Khairat mampu membentuk perubahan nilai sosial keagamaan, orientasi ekonomi, dan orientasi sosial politik. Keberhasilan para pengamal Dalaíl dalam menekuni usaha bisnisnya juga tidak terlepas dari kekuatan dan pemahamannya tentang Islam. Ketaatan terhadap Islam menjadikan faktor yang mendorong berkembangnya usaha bisnis, meskipun bukan penentu satusatunya, agama Islam-terutama dalam bingkai amalan memperbanyak shalawat telah memberi pengaruh terhadap usaha ekonomi para pengamal. Usaha-usaha dalam mencapai kesuksesan ekonomi melalui pengembangan potensi masing-masing pengamal; adanya keseimbangan waktu dalam pengembangan usaha; dan yang terpenting legitimasi dari peran pemerintah setempat. Semua faktor 
tersebut dapat mendorong terjadinya akumulasi kekayaan dan telah melahirkan semangat kerja keras, tekun, dan hemat. Agama dalam konteks ini adalah amalan Dala'il Kabirat telah menjadi faktor penyebab berkembangya komersialisasi di kalangan para pengamal yang memiliki usaha dan telah membantu proses pencapaian keberhasilan dibidang ekonomi. Demikian juga, dengan faktor-faktor yang lain, seperti: pengalaman spiritual, sifat-sifat kejujuran, keterbukaan, dan kebersamaan dapat mendinamiskan praktek-praktek ekonomi mereka.

Reformasi agama telah menumbuhkan watak tekun, kerja keras, hemat, rasional, serta tidak mudah putus asa. Ajaran tentang berpuasa yang memberikan penekanan terhadap upaya efisiensi menuju kekayaan telah menumbuhkan sikap tekun dan kerja keras di kalangan para pengamal Dala'il Khairat.

Islam dalam hal ini menjadi simbol struktur yang menempatkan mereka pada strutur sosial yang lebih tinggi dalam masyarakat. Mereka menjadi kelas menengah bahkan kelas atas yang turut mempengaruhi dinamisasi kehidupan masyarakat disekitarnya. Disini struktur juga memainkan peran penting untuk menjelaskan mengapa para pengamal Dalaíl Khairat yang menjadi pengusaha berhasil mengembangkan usaha mereka dan dapat terus bertahan.

Pada kenyataanya, amalan Dala'il Khairat bukanlah faktor penentu satu-satunya. Dalam pembahasan terdahulu tentang identitas sebagai pengamal yang memiliki relasi sosial di kalangan masyarakat sangat baik, mereka mampu membagi waktu antara ibadah dengan bermasyarakat, memiliki komitmen untuk jujur, saling terbuka, dan berbagi dalam kebersamaan, dan hal penting lagi adalah desain usaha yang disupport dengan kebijakan pemerintah. Semua ini merupakan beberapa variabel yang tampak menjadi pertimbangan para pengamal dalam transaksi kemampuan berintegrasi dalam struktur setempat menjadi salah satu variabel penentu.

Amalan Dala'il Khairat telah memberi dukungan moral dan ideologis. Etos-etos kekayaan tertentu menjadi pemerkuat dan bersesuaian dengan keadaan lingkungan. Hal ini memberi kesan bahwa dalam kehidupan komersial mereka, amalan Dala'il Khairat 
memainkan peran penting, baik secara motivasional maupun institusional, identitas Islam serta kepemilikan kekayaan yang saling memperkuat, menempatkan para pengamal pada suatu struktur sosial yang baik.

Kesalehan ritual mereka memperlihatkan bagaimana amalan dala'il Khairat-telah menyumbang dalam pembentukan etos-etos mereka, meskipun hal itu bukan faktor satu-satunya yang menentukan kemampuan mereka berhasil. Islam diyakini penganutnya memberi perasaan bangga dan kekuatan bertahan dalam menjalankan proses usaha. Ungkapan bahwa Islam melarang orang putus asa dalam berusaha dan harus sabar dalam menjalani usaha merupakan ungkapan dari gagasan tersebut. Karena itu, bisa dimengerti bahwa ketika mereka bergiat dalam usaha, mereka terlihat tahan uji. Mereka memiliki semangat komersialisasi: hemat, kerja keras, tekun, tahan uji, dan berperhitungan.

Selanjutnya, dengan spirit Dala'il Khairat dapat memberi pengaruh terhadap etos kerja dan peningkatan ekonomi santri. Hal ini bisa dilihat bahwa pengalaman spiritual sebagaimana yang dijelaskan dalam pembahasan, bahwa dengan melaksanakan wirid Dala'il Khairat, para pengamal bias memperoleh spirit untuk mencapai sebuah kesuksesan. Kesuksesan disini tidak hanya dikategorikan sebagai sukses bentuk materi, melainkan kepuasan perasaan setelah mengamalkan dala'il.

Sebagian besar informan memiliki keyakinan bahwa dengan melaksanakan amalan Dala'il Khairat ini, mereka pada umumnya akan dihadapkan dengan sebuah ujian dan cobaan yang berbedabeda, baik itu berasal dari diri pribadi maupun orang lain terdekatnya (keluarga). Jika para pengamal lulus menghadapi ujian dan cobaan, maka dia akan diangkat derajat keilmuanya dan diberikan kesuksesan hidup. Dilihat dari praktek pengamalannya, maka dapat dilakukan sebuah proses identifikasi terhadap beberapa nilai-nilai, etika, dan spirit santri dalam mencapai sebuah kesuksesan yang diharapkan dapat muncul atau melakat pada diri santri: pertama, pentingnya sebuah kemantaban dan keyakinan diri bagi seorang santri dalam menjalani setiap apa yang akan dikerjakan; ke-dua, pentingnya sebuah semangat kerja keras, kedisiplinan, keuletan, dan sistem manajemen dalam mengelola waktu dan kesabaran bagi seorang 
santri dalam menjalani sesuatu atau mencapai sebuah tujuan tertentu; ke-tiga, pentingnya bagi seorang santri untuk dapat menjaga keseimbangan antara ibadah ritual dengan bekerja mencari nafkah; ke-empat, pentingnya santri untuk dapat menahan hawa nafsu, rasa lapar, dan haus serta menahan untuk tidak melakukan hal-hal yang bersifat negatif atau dilarang oleh ajaran agama (kecurangan, penipuan, kebohongan, dan perbuatan-perbuatan negative lainnya); ke-lima, dalam melaksanakan sesuatu, seorang santri seharusnya menyesuaikan dengan kemampuan dirinya atau tidak memaksakan diri, yang penting santri melaksanakannya secara kontinyu, sehingga dari hal yang berat tersebut menjadi ringan; ke-enam, pentingnya keyakinan yang kuat dari seorang santri, bahwa apabila sudah bekerja keras dan berdoa, rizki itu pasti akan datang juga; ke-tujuh, apabila tujuan santri sudah tercapai, disarankan agar santri segera bersyukur pada Alloh SWT dengan membiasakan membaca riwayat Syaikh Abdul Qadir Jaelani; ke-delapan, ujian dan cobaan yang dihadapi santri adalah hal yang biasa terjadi dan akan merintangi santri untuk mencapai tujuannya, sehingga kemunculan ujian dan cobaan ini seharusnya tidak membuat santri untuk berhenti/patah semangat dalam mencapai tujuan yang ingin dicapainya; ke-sembilan, dibalik sebuah ujian dan cobaan yang dihadapi santri tersebut pasti ada hikmah positif yang lebih besar; ke-sepuluh, pentingnya arti nasehat dan motivasi guru (orang yang memiliki pengalaman lebih berkaitan dengan apa yang hendak kita lakukan) untuk menjaga keberlangsungan dan keberhasilan pada setiap tujuan yang ingin dicapai santri; ke-sebelas, pentingnya silabturohmi atau menjalin komunikasi dan menjaga ke-istiqomah-an antara guru dengan murid.

Sementara bentuk-bentuk ikhtiar santri dalam meraih kesuksesan di bidang ekonomi lebih banyak didorong atau dipengaruhi oleh beberapa faktor, antara lain: keberadaan spirit "Dala'il Khairat" pada diri santri yang kemudian bermuara pada kebangkitan ekonominya. Faktor-faktor struktur sosial budaya yang ada, misalnya keseimbangan waktu antara ibadat dengan pengelolaan usahanya, peran pemerintah atau pola hubungan yang dijalin dengan birokrasi pemerintahan, adanya penerapan manajemen dan teknologi modern, penerapan etika bisnis Islam, dan pertumbuhan budaya intelektual santri. 


\section{Daftar Pustaka}

Abdullah, Irwan. 1994. The Muslim Businessmen of Jatinom: Religious Reform and Economic Modernization in a Central Javanese Town. Disertasi Ph.D. University of Amsterdam. , 2003. Tumbuh dan Berkembangnya Kaum Pengusaha di Aceh. Yogyakarta: Relief Press.

Abdullah, Taufik (ed.). 1978. Agama, Etos Kerja, dan Perkembangan Ekonomi. Jakarta: LP3ES.

Aedy, Hasan. 2007. Indahnya Ekonomi Islam. Bandung: Alfabeta. Agama, Departemen RI. 1989. Al-Qu'an dan Terjemahnya. Jakarta: Bagais Depag.

Ahmad, H.R.. 2006. Etos Bisnis Kaum Muslim. Jakarta: Majalah Gatra Edisi Khusus Leberan 2006.

Al-Taftazani. 1984. Sufi dari Zaman ke Zaman, terj. Ahmad Rofi' Usmani, Bandung: Pustaka.

Alwies, M. Rusli. 2000. Agama Perspektif Antropologi; Suatu Analisis Teoritis Pendekatan Kebudayaan. Solo: STAIN Press.

Asy'arie, Musa. 1997. Islam-Etos Kerja dan Pemberdayaan Ekonomi Umat. Yogyakarta: LESFI.

Azami, Muhammad Mustafa. 1992. Motodologi Kritik Hadis. Penterjemah: A. Yamin. Jakarta: Pustaka Hidayah.

Azizy, A.Qodri. 2005. Cara Kaya dan Menunai Surga. Jakarta: Renaisan.

Basyir, K.H Ahmad. 1992. Naylul Masyarat fi Taskhih Dala'ilul Khairat. Kudus: Menara Kudus.

Buko, Cholid Nar dan Achmadi, Abu. 1997. Metodologi Penelitian. Jakarta: Bumi Aksara.

Castle, L.. 1982. Tingkah Laku Agama, Politik dan Ekonomi di Jawa: Industri Rokok Kudus. Jakarta: Penerbit Sinar Harapan.

Depdiknas. 2002. Kamus Besar Bahasa Indonesia. Jakarta: Balai Pustaka.

Feillard, Andre. 1999. NU Vis-a-vis Negara: Pencarian Isi, Bentuk, dan Makna, Terj. Lesmana, Yogyakarta: LkiS.

Geertz, Clifford. 1989. Abangan, Santri, Priyayi Dalam Masyarakat Jawa. Jakarta: Dunia Pustaka Jawa. 
1977. Penjaja dan Raja Perubahan Sosial dan Modernisasi Ekonomi di Dua Kota Indonesia. Jakarta: P.T Gramedia.

- 1974.

The Interpretation of Culture. New York: Basic Book.

Hadi, Sutrisno. 1990. Metodelogi Reseach. Yogjakarta: Fakultas Psikologi UGM.

Hefner, Robert.W. 1998. Geger Tengger-Perubahan Sosial dan PerkelabianPolitik. Penerjemah: A Wisnuhardana dan Imam Ahmad. Yogyakarta: LkiS.

Husein, Thaha. tt. Al-Ayyam, Jilid II, Kairo: Darul Ma'arif.

James, William. 1974. The Varieties of Religious Rxperience, New York: The New America Library.

Kisbiyanto dkk.. 2000. Sejarah Pengarang Kitab Dalailul Khairat Syakh Abu Abdillah Muhammad bin Sulaiman al-Jazuli. Kudus: PP Darul Falah Jekulo Kudus.

Moleong, Lexy J. 1991. Metodologi Penelitian Kualitatif. Bandung: Remaja Rosda Karya.

Muhaimin, Yahya. 1987. Muslim Traders:Tehe Stillborn Bourgeoisie. Prisma.

Mu'tasim, Radjasa dan Mulkhan, Abdul Munir. 1998. Bisnis Kaum Sufi. Yogyakarta: Pustaka Pelajar.

Patanto, Pius A dan Al Barry, M. Dahlan. 1994. Kamus Ilmiah Populer. Surabaya: Penerbit Arkola.

Pelly, Usman dan Menanti, Asih. 1994. Teori-Teori Sosial Budaya. Jakarta: Proyek Pembinaan dan Peningkatan Mutu tenaga Kependidikan Direktorat Jenderal Pendidikan Tinggi Departemen Pendidikan dan Kebudayaan.

Sairin, Sjafri. 2002. Perubahan Sosial Masyarakat Indonesia Perspektif Antropologi, Yogyakarta: Pustaka Pelajar.

Usman, M. Ali dan Dahlan, M., 1994. Hadits Qudsi; Pola Pembinaan Akhlak Muslim. Bandung: Diponegoro.

Weber, Max. 1992. Etika Prostestan dan Spirit Kapitalisme. Penerjemah: TW Utomo dan Yusuf Priya Sudiarja. Yogyakarta: Pustaka Pelajar Offset.

Majalah, Surat Kabar, dan Situs Internet 
Abdul Jalil

Gatra, 25 Oktober 2006

Suara Merdeka, 09 November 2004

www.studiislam.com

www.sunnah.org

www.naqshabandi.org

www.naksibendi.org

www.figurpublik.com 